\title{
Property Rights Transfer of Land Under Government Regulation Number 24 of 1997 on Land Registration in The Semarang City
}

\author{
Ida Fitriany ${ }^{1}$ and Akhmad Khisni ${ }^{2}$
}

Abstract. The problem in this research is how the implementation of the transition land ownership through of buying and selling in Semarang?, and What are the barriers and solutions to transition ownership of the land by way of sale and purchase in Semarang? Sociological juridical approach, specification of descriptive analytical research. Source of Data are Primary and Secondary Data. Research technique purposive sampling non-random sampling. Data collection techniques by observation and interviews and conducted through the study of literature. Data Analysis Techniques with qualitative analysis methods.

The results of the study in this paper the problem is still a delay in registration of transfer of property rights on land that is done by selling under the counter. Pleased with the legal cover for land buyers when buying and selling is done under the hand and is not registered with the Land Office, it is for the buyer of land is not legally strong / weak and limited. It is the duty of the buyer to complete the land to make a statement of deeds delays, physical mastery statement and the statement is not in dispute. The land buyers are often disadvantaged by the implementation of the sale and purchase under the hand, because when to create a deed, the seller had died or had not known where he lived.

Keywords: Sale and Purchase of Land, Transfer of Rights, and Government Regulation No. 24 of 1997 on Land Registration.

\section{Introduction}

In order to create the ground for justice and prosperity, the direction and policies of land based on the four (4) principles: ${ }^{3}$

- Land should contribute to the welfare and prosperity of open access, especially through access to agrarian resources;

- Land should contribute to creating fairness with regard to control, ownership, use and utilization of land;

- Land should contribute to creating sustainable systems and agrarian resources towards the creation of a social system, nationhood and statehood;

- Land should contribute to reducing land disputes and conflicts in creating a harmonious order of life together.

\footnotetext{
${ }^{1}$ Students of Master of Notary Law UNISSULA Semarang email: idafitria822@gmail.com

2 Lecturer in Faculty of Law UNISSULA Semarang

33oyo Winoto 2010 Teks Sambutan Kepala BPN RI pada Upacara Peringatan 50 tahun Agraria tanggal 24 September 2010 Pusat Hukum dan Hubungan Masyarakat BPN RI Jakarta.
} 
Based on four (4) principles of land management, the government through the National Land Agency of the Republic of Indonesia has formulated a priority agenda, one of them namely: Ensure the strengthening of the people's rights to land that can be seen as a strategy to achieve justice and welfare.

Under the provisions of Article 19 paragraph (1) and (2) BAL mentioned:

- In order to ensure legal certainty by the Government land registration throughout the territory of the Republic of Indonesia in accordance with the provisions stipulated in Government Regulation.

- The registration referred to in paragraph (1) of this article include:

- Sizing, mapping, and soil bookkeeping;

- Registration of rights to land and transfer of such rights;

- Giving letter of proof of the rights, which serves as a powerful verification tool. Under the terms of the registration of land as referred Article 19 paragraph (1) abovementioned BAL is a legal registration (rechtcadaster or legal cadaster). In the context of the registration law, land registration into commands legislation to the Government to establish a Government Regulation (PP) on the registration of land, in this case the Government Regulation No. 10 of 1961, which subsequently has been replaced and improved by Regulation No. 24 of 1997, Gazette the Republic of Indonesia Number 59 Of 1997 on Land Registration, where registration is decisive in the development process of the country.

Buying and selling land is legal actions in the form of delivery of property rights to land (land surrender forever) by the seller to the buyer at that time the buyer has the price to the seller. Sale and purchase that resulted in the shift of land ownership from seller to buyer included in the law or the law of the land. ${ }^{4}$

The sale and purchase of land titles are made not through PPAT especially in Semarang mostly done by people who are weak economic situation and the level of education is low. Society does not understand the positive law, because of the influence of customary law which determines that the sale and purchase of land rights is legitimate if bright and cash requirements are met. In addition, the low public interest in the certification of land for public understanding of the certificate as proof of land rights is still lacking, even they still found girik is evidence of land rights, but girik is proof of tax payment and most members of the community do not understand the provisions of land law, especially concerning land registration.

Although customary law confirmed the validity of the sale and purchase of land that was not done before PPAT often called in the bargain under the hand, the buyer obviously had difficulty proving their rights to land that has been purchased already certified for the absence of a deed of sale of land made before PPAT difficult for buyers to register their land rights in the Land Office. Head of the Land Office has clearly

4 Boedi Harsono in Urip Santoso 2010 Pendaftaran dan Peralihan Hak atas Tanah cet.1 Kencana Prenada Media group Jakarta p. 360. 
rejected for registration with the transition right under Article 45 of Government Regulation No. 24 of 1997.

Furthermore, Article 37 paragraph (1) Regulation No. 24 of 1997 states the requirement to register transfer of rights to use deed PPAT, the deed of sale of land made before PPAT serve as a proof of the ownership of the land for the purposes of registration on behalf of the buyer as the rights holder last, PPAT can not make the deed of sale of land in front of him because of non-fulfillment of the terms of material and formal requirements of buying and selling land, in terms of material for the sellers, among others, the same name as listed in the certificate and adult (ably do the law), for land buyers requirement their material is a citizen of Indonesia.

In this research has found cases of non-fulfillment of the terms of material and formal requirements in the implementation of transitional registration of property rights to land through purchase in the Land Office of Semarang. Sellers and buyers are only buying and selling under the hand of the created receipts and do not proceed with the making of the deed of sale before PPAT, resulting in the development of the expense of the purchaser of land, the land buyers find it difficult at the moment will be made deeds as sellers of land is not in place and no known address.

Based on the description of the background of the above, the authors are interested to examine it. The research in this thesis entitled: "Transfer of Rights Owned Land In A Sale and Purchase Based on Government Regulation No. 24 of 1997 on Land Registration in Semarang".

Based on the above title, the problem in this research are:

- How the implementation of the transition land ownership by means of buying and selling in Semarang?

- What constraints and solutions in transfer of property rights to land by way of sale and purchase in Semarang?

\section{Research methods}

Sociological juridical approach, specification of descriptive analytical research, Source of Data Primary and Secondary Data. research technique purposive sampling non-random sampling. The data collection technique: Primary data with observations and Interview and secondary data is done through the study of literature. Data Analysis Techniques with qualitative analysis methods.

\section{Results and Discussion}

\subsection{Implementation of the Transitional Registration Property Rights to Land By Way Of Buying And Selling In The Semarang city.}

The practice of Registration of Transfer of Rights Owned Land in the Land Office of Semarang, in accordance with the provisions of Regulation No. 24 of 1997 jo PMNA No. 31997 can be divided into three (3) phases, namely the phase of preparation of 
the deed, deed implementation phases and stages after the deed (registration to the Land Office) is as follows:

- Preparation of Deed

According to the Circular of the State Minister of Agrarian Affairs / Head of National Land Agency No. 04-1198, dated 1 April 1999 the aspect of legal actions that clarity is the responsibility of PPAT namely:

- The truth of the events contained in the deed;

- Regarding the object of legal actions, both physical data and juridical data;

- Regarding the identity of the parties penghadap a party to legal actions.

Based on interviews with PPAT, that the practice of making the transition deed of land rights can be explained as mentioned above as follows:

- Submission of Application Preparation of Deed by the Parties

- Examination Certificate in Land Office

- Making Implementation Deed

Deed PPAT must be witnessed by at least two witnesses, according to the legislation in force qualified to act as a witness in a legal act, testifying among others, the presence of the parties or their attorneys, the existence of the documents shown in deed, and has been the implementation of the legal acts by the parties concerned. PPAT shall read the deed of sale to the parties concerned (buyers and sellers) and provide an explanation regarding the content and purpose of the deed and registration procedures switchover rights.

- Registration of Transfer of Rights to Land

The registration of transfer of property rights to do with the delivery of the signed deed accompanying document to the Chief of the Land Office of Semarang, in accordance with the provisions of Article 40 of Government Regulation No. 24 of 1997 in conjunction with Article 103 Regulation of the State Minister of Agrarian Affairs / Head of National Land Agency Number 3, 1997, PPAT shall submit certificates and other documents required for the purposes of registration of transfer of rights concerned to the Land Office not later than seven (7) working days from the signing of the deed which connected.

Under these provisions there are two (2) important records that can be written as follows:

- The obligation to register transfer of title for the land by way of sale and purchase is official Notary / PPAT and sub-district officials as temporary PPAT.

- The term of registration is done by PPAT to the Land Office not later than seven (7) working days.

Based on research at the Land Office of Semarang authors have obtained the registration application data transition of land rights by way of purchase of late been registered in the Land Office Semarang. From the data, it can be seen that the delay of registration of transfer of rights (delivery of a deed of sale) to the Land Office of Semarang carried out by sub-district as officials PPAT not Notary PPAT for Notary PPAT 
directly convey / register deeds of sale have been signed to the Land Office, while camat as a public official time used to deal with the government.

Delays in the delivery of the deed and the paperwork for registration by PPAT to the Land Office does not result in the cancellation of the deed is concerned and according to the author of such provisions for granted, because of the negligence of PPAT to register a deed of PPAT within the time limit prescribed by the Act, namely no later than 7 (seven) days after the signing of the deed did not deserve to make the interests of the parties be ignored and it is fitting also PPAT sanctioned on careless, therefore the legal consequences of the offenses set forth in Article 40 of the above, according to the provisions of Article 62 Regulation No. 24 of 1997 is only levied against PPAT concerned, while the consequences or the deed of the land can be registered.

Deed of sale made by PPAT can still be registered by the Land Office deeds late although the date of signature, the buyer of land must attach a statement that contains:

- Reasons for delays, for example:

- Applicant negligence

- Do not have any money to register

- The land was physically overpowered

- The land is not in dispute

- Subject and object as stated in the deed of sale has not changed

\subsection{Obstacles And Solutions In Transfer Of Property Rights To Land By Way Of Sale And Purchase In Semarang}

Currently the community generally, many are shackled with problems of land documents that should be demonstrated as proof of his own when the physical evidence had mastered so many years even decades, so people do not get legal certainty on the status of land owned, because of lack of knowledge public about the Land law or Regulations on Land.

- Community assumption that the Sale and Purchase Agreement under the hand and with the already strong PPAT deed legally

The rationale of the people who are not willing to register the transfer of land rights can be expressed as follows:

- With the current state of the land owners feel has been protected by law since besides recognized by the Government (through the receipt of tax payment) as well as proof of land ownership.

- Felt ashamed / embarrassed when buying and selling along with signature purchase receipt or letter because it seems not to trust others.

- Land legacy should not change the status, left as usual, so no need to return the name and questioning taboos inherited land, let alone to divide and sell.

- Land is not an object that has economic value, but more likely to have a religious magical value. 
- There is a very close bond between the owner of the land with the land, so that the rare transition of land rights.

- Sale and Purchase of Land with PPAT deed is considered valid

Deed of sale of land made by the Land Deed Official (PPAT), has a function, namely:

- To prove, authentically has the particular plot of land purchase, on certain days, by certain parties mentioned therein.

- As purchasing requirement for sales registration to the local Land Office.

- Here is a proof of the weakness of legal guarantees for rights holders last / buyer

- No clear certainty that the rights listed status

Can not be known with certainty the status of the rights that are listed, for example Properties, leasehold, Broking, Right to Use, Rights Management, Mortgage, Property Rights Over Land Force Flats or Waqf.

- Clearly no certainty the subject of rights

Can not be known with certainty the rights holder, whether individual (Indonesian citizens or foreigners domiciled in Indonesia), a group of people together, or a legal entity (legal entities of private or public legal entity).

- Unclear certainty of rights objects

Can not be known with certainty lay of the land, land boundaries, and size (area) of land. Lay of the land is in the street, urban / rural, district, county / city, and where the province. The boundaries of land covering north, south, east, and west by the land who or what land.

- For rights holders, the Government and the prospective buyer of land, the next will not get benefits.

- For rights holders

- Do not give a sense of security.

- Unable to determine clearly the physical data and the data juridical.

- Difficult in the implementation of the transfer of rights.

$\checkmark$ Land prices remain low.

- Difficult serve as collateral Mortgage debt burdened.

- Determination of Land and Building Tax (PBB) is easily mistaken.

- For the Government

- Inhibiting the orderly realization of the land administration as one of the chess program tongue Land.

- Inhibiting activity related to land administration in development.

- Tend to increase in land disputes, such as disputed land borders, illegal occupation of land.

- For prospective buyers or creditors

For prospective buyers or potential creditors will be difficult to obtain a clear explanation of the physical data and juridical data of land that will be the object 
of a legal act on the ground. Sale and purchase of legal protection under the hands of the weak is also limited.

In the register transfer of rights on land that has been certified through buying and selling, especially in this case the sale and purchase of land that has been certified which is not done in the presence of PPAT while one party is the holder of the right long / owner of the certificate (the seller) is no longer known address or had died, and his heirs had no known address, the Land Office to use the contents of the District Court's decision is legally binding as a legal basis for carrying out the registration procedure switchover rights.

The role of the decision of the District Court (PN) as the basis for transfer of rights to land through purchase is if the land purchase is done under the hands of the land that has been certified (without having made a deed of sale of land in front of PPAT) and seller or their heirs had died and or is no longer known address. The role of PN verdict can be seen from the two parties, namely the Land Office and last rights holder (buyer).

\section{Closing}

\subsection{Conclution}

- Implementation of the Transitional Registration Property Rights to Land by way of buying and selling in the Semarang city.

Delays in the delivery of the deed and the paperwork for registration by PPAT to the Land Office does not result in the cancellation of the deed is concerned and according to the author of such provisions for granted, because of the negligence of PPAT to register a deed of PPAT within the time limit prescribed by the Act, namely no later than 7 (seven) days after the signing of the deed did not deserve to make the interests of the parties be ignored and it is fitting also PPAT sanctioned on careless, therefore the legal consequences of the offenses set forth in Article 40 of the above, according to the provisions of Article 62 Regulation No. 24 of 1997 is only levied against PPAT concerned, while the consequences or the deed of the land can be registered.

- Obstacles and solutions in transfer of property rights to land by way of sale and purchase in Semarang City

Efforts are being made if the holders of land titles through the late PPAT registration of transfers of rights to the Land Office of Semarang is a requirement to make a statement that contains the delay Reason for delay; Land physically controlled and not in dispute; Subject and object rights switchover no change.

\subsection{Suggestion}

- Importance conducted counseling intensively by government officials, especially the Land Office together electronic media or scheduling directly into the villages with 
the intention that the legal awareness of the public to register transfer of rights to the Land Office to increase, so the public will get a strong legal protection for his land with obtain property rights certificates as proof of ownership of their land rights.

- Importance of Judicial Decision already legally binding as the basis for transfer of rights over land by way of sale and purchase under arms, will remind the judges in handling and deciding the case lands in court that kept digging and trying to find a new law that originates and is rooted in a sense of justice and siding with the landowners as a buyer with good intention.

\section{Bibliography}

[1] Joyo Winoto 2010 Teks Sambutan Kepala BPN RI pada Upacara Peringatan 50 tahun Agraria tanggal 24 September 2010 Pusat Hukum dan Hubungan Masyarakat BPN RI Jakarta.

[2] Boedi Harsono in Urip Santoso 2010 Pendaftaran dan Peralihan Hak atas Tanah cet. 1 Kencana Prenada Media group Jakarta.

[3] Constitution of the Republic of Indonesia Of 1945;

[4] Act No. 5 of 1960 on Basic Regulation of Agrarian (BAL);

[5] Government Regulation No. 24 of 1997 on Land Registration;

[6] Decree of the President of the Republic of Indonesia Number 26 of 1988 which has been amended several times and last amended by Presidential Decree of the Republic of Indonesia Number 10 Of 2006 on National Land Agency;

[7] Minister of State for Agrarian Affairs / Head of National Land Agency No. 3 of 1997 on the Implementation of Government Regulation No. 24 of 1997 on Land Registration;

[8] Minister of State for Agrarian Affairs / Head of National Land Agency Number 1 of 2006 on the Implementation of the Provisions of Government Regulation No. 37 of 1998 on the Regulation of Land Deed Official Position. 